\title{
Kansei engineering approach for developing electric motorcycle
}

\author{
Dawi Karomati Baroroh ${ }^{\mathrm{a}^{*}}$, Mya Amalia ${ }^{\mathrm{a}}$, Nur Puji Lestari ${ }^{\mathrm{b}}$ \\ ${ }^{a}$ Department of Mechanical and Industrial Engineering, Universitas Gadjah Mada \\ Jl. Grafika 2 Yogyakarta, 55281, Indonesia \\ ${ }^{b}$ Study Program of Industrial Technology, Institute of Technology and Science Nahdlatul Ulama Pekalongan \\ Jl. Karangdowo 9 Pekalongan, 51173, Indonesia
}

Article history:

Received: 22 July 2019 / Received in revised form: 29 November 2019/ Accepted: 1 December 2019

\begin{abstract}
Electric vehicles are considered as one of the solutions to reduce vehicle emissions into the environment. However, the enthusiasts' number of the electric motorcycle is relatively low. In order to escalate product and competitive value in the market, the design elements of the electric motorcycle have to develop. The aim of this research is to design an electric motorcycle that appropriates with user needs and desires by utilizing Kansei engineering approach. This study involved 212 respondents for the semantic differential I and 204 respondents for the semantic differential II. The results of this study were 14 pairs of Kansei words, which were used to evaluate 11 sample designs where there were 5 items and 14 design categories. The design specifications of the most dominant electric motorcycle were a design with angled seat, type 1 of front hood, 2 slots for luggage box, type 3 of headlight, and type 2 of body hood.
\end{abstract}

Keywords: Electric Motorcycle; Kansei Engineering; Semantic Differential.

\section{Introduction}

The success of technological advances provides a lot of convenience and comfort in human life, but it also increases many problems and damage in human life, such environmental pollution. Pollution from fossil fueled vehicle engines is one of the causes. Therefore, to reduce vehicles' emissions, the use of electric vehicles is one of the global plans to be developed. The drafting of regulations relating to electric vehicles and also the design of general electric charging stations in several regions has begun in Indonesia [1]. The motorcycles number in Indonesia has increased by an average of $10 \%$ per year over the past 10 years, and around $82 \%$ are dominated by motorcycles [2]. This vehicle type is very popular as urban transportation, which is synonymous with a large amount of air pollution. It's because urban transportation requires low permissive speeds and also carries out a lot of braking and movement cycles, resulting in incomplete combustion and more air pollution being released [3].

The presence of electric motorcycles in Indonesia has received positive responses from various parties. Apart from motorcycle manufacturers, several universities in Indonesia have also participated in research and developing electric motorcycles. For instance, the Garansindo and BOSCH companies have been collaborating with the Sepuluh Nopember Institute of Technology (ITS) to develop "GESITS" electric motorcycles. Meanwhile, the VIAR and $\mathrm{BOSCH}$

* Corresponding author.

Email: dawi.karomati.b@mail.ugm.ac.id companies have been collaborating with Universitas Gadjah Mada (UGM) in developing the "VIAR Q1" electric motorcycle.

In the context of reducing vehicle emission, the using and selling of electric motorcycles must be increased, but the number of enthusiasts is still relatively really low. Based on previous research, design elements are greatly important things to increase both product and competitive value [4]. In determining a product design, the company needs to consider the consumer's desires. The success of a company in developing a product depends on its ability to identify consumer needs and create products that can fulfill those needs [5].

Kansei Engineering is one method of developing productoriented to the needs and consumers' desires. This method specifically analyses the implicit needs of consumers and relates them to the product design character. It is crucial because consumers cannot always explain their desires explicitly. Kansei products are considered to be able realizing the needs and emotions of consumers by considering various aspects of the functions, forms, and desires of consumers so that they will produce good and valuable products to market [6]. Some examples of successful Kansei products are Mazda Miata cars, Sharp refrigerators, Wacoal Good-up Bra, etc. [7]. Therefore, this paper presents an electric motorcycle design with the Kansei Engineering approach, which is expected to be able to produce design elements to fulfill consumer's needs and wants. This result is also expected to increase consumer 
enthusiasm for electric motorcycle products in the future.

\section{Kansei Engineering Approach}

Kansei engineering is a method for translating Kansei from humans into product design elements [8]. Generally, the principal of Kansei engineering starts with exist of human input sensors (vision, hearing, sight, smell, and taste) which is able to form one's kansei, and it can develop feeling emotion. Besides, humans also have a chisei in themselves. With the same input, chisei builds logical knowledge through various learning processes. The output produced is then poured into a questionnaire form. This data is believed to represent a person's chance for a product or product design element (can be seen in Fig. 1).

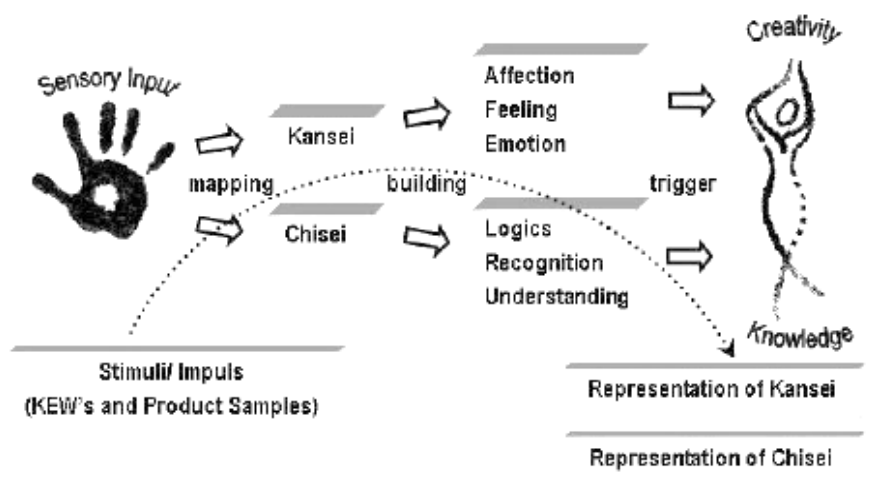

Fig. 1. Kansei engineering principles [8]

\section{Materials and Methods}

The research has been performed with the object in the electric motorcycle form in several design types, especially classic and sporty types, while the subject of this study is users or drivers either in fuel or electric motorcycle. This research has several steps, which are described clearly in Fig. 2.

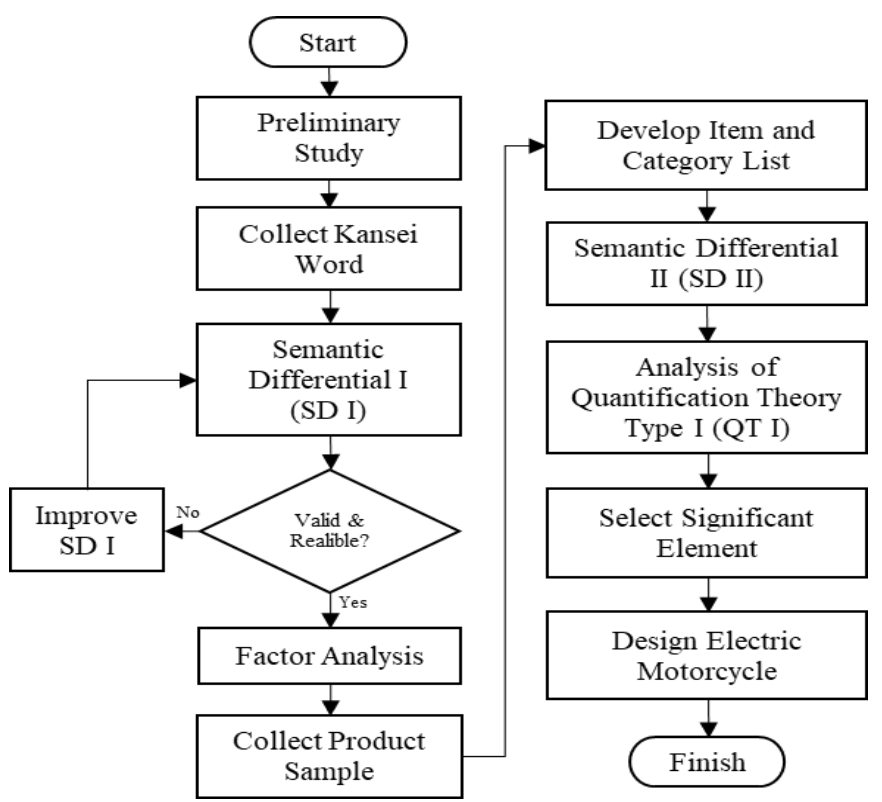

Fig. 2. Flowchart of research methodology

\subsection{Preliminary study}

The stage of a preliminary study was executed by distributing questionnaires online using Google form to respondents for opting for the important parts from 21 parts of the motorcycle which is considered when the user is choosing a motorcycle. It aimed to determine electric motorcycle parts, which would be the focus of this research.

\subsection{Collection of kansei words}

Kansei word was collected by doing a literature review to several previous studies. It has been done not only from studies about electric motorcycle design but also from other electric vehicle studies, which still related to this research.

\subsection{Semantic differential I}

All of kansei words then would be evaluated using semantic differential I (SD I) questionnaire. In this instrument, there were seven scales for each pair of kansei words. The following was an example of the SD I measurement scale used in the study (described in Fig. 3).

\begin{tabular}{|l|l|l|l|l|l|l|}
\hline Bright & 2 & 3 & 4 & 5 & 6 & 7 \\
\hline
\end{tabular}

Fig. 3. Semantic differential I (SD I) Scale

Before the questionnaire was widely distributed to respondents (using Google form), it was tested first in a pilot test to check the validity and reliability of each item in the questionnaire. In the validation test, the kansei word will be valid if the value is rcalculate $\geq$ rtable. If there is an invalid word kansei then the word is omitted, and the questionnaire is tested for validity again until all the words kansei are declared statistically valid. Then the reliability test is used to determine the level of consistency of the answers of respondents. This testing process was carried out using SPSS 21.

\subsection{Factor analysis}

Factor analysis is a statistical method that is used to reduce the word kansei from the SD Questionnaire I. This process was carried out using software $\mathrm{R}$, to assess the contribution of each word kansei to each factor. This stage began with testing the Kaiser Meyer Olkin (KMO) and Bartllet Test, then evaluated Measure Sampling Adequacy (MSA) by Anti Image Correlation.

\subsection{Collection of product samples}

Design samples of electric motorcycle products (in the form of images) are used to collect the image of electric motorcycles and describe the design items and categories, in which the images were obtained from sales websites and articles related to electric motorcycles.

\subsection{Item and category determination}

Items are a design element of electric motorcycles based on 
the results of preliminary study, while categories are variations on each design element, which was resulted from the benchmarking process with existing or commercial electric motorcycle products (product samples).

\subsection{Semantic differential II}

The semantic differential II (SD II) aimed to determine the relationship of each product sample with the word pair Kansei. This questionnaire is in the form of a semantic differential with seven scales which distributed using Google form (the detail process similar to SD I process).

\subsection{Quantification theory type I}

The quantification theory type I (QT I) process was a method to analyze the significant elements by using SPSS 21 and R program. The data required in the QT I process is the average value of the kansei word pairs, which obtained from the SD II questionnaire and the design element categories of each sample.

\subsection{Final design}

Significant design elements will be selected as product design elements and will be used to draw 2D/3D designs (using Corel Draw software and Autodesk Inventor). For developing 2D/3D design, some detail dimensions relating to human anthropometry, it was based on the previous study, as shown in Table 1.

Table 1. Part dimension related to anthropometry [9]

\begin{tabular}{clc}
\hline No & \multicolumn{1}{c}{ Electric Motorcycle Part } & Size $(\mathrm{cm})$ \\
\hline 1 & Steering Wheel & $58.3-70.29$ \\
\hline 2 & Handlebar Width & $8.67-12$ \\
\hline 3 & Handlebar Diameter & $3-3.5$ \\
\hline 4 & Distance from Handlebar to Brake Lever & $4-5$ \\
\hline \multirow{2}{*}{5} & $\begin{array}{l}\text { Distance from Handlebar to Horn Button, } \\
\text { to Light Switch Button }\end{array}$ & $3-4$ \\
\hline 6 & Driver's Footrest Length & $29.5-35$ \\
\hline 7 & Passenger Footrest Width & $11.5-13$ \\
\hline 8 & Height from Saddle to Footrest & $43.5-48.32$ \\
\hline 9 & Height from Saddle to Ground Level & $67.23-75$ \\
\hline 10 & Saddle Width & $30.1-43.08$ \\
\hline 11 & Driver Saddle Length & $39.68-47.7$ \\
\hline 12 & Passenger Saddle Length & $27.77-33.39$ \\
\hline 13 & Overall Saddle Length & $67.45-81$ \\
\hline
\end{tabular}

\section{Results and Discussion}

\subsection{Preliminary study}

In the preliminary study, which completed by 50 respondents (with demography as depicted in Table 2), it was obtained that there was more than half percent $(50 \%)$ of respondents chose 5 of 21 the electric motorcycle parts as important things. They were seat, front hood, headlights, luggage box, and body hood (as shown in Fig. 4). The five parts will be the focus of development or design in this research.

Table 2. Demography of respondents (preliminary study)

\begin{tabular}{|c|c|c|c|}
\hline & & People & $\%$ \\
\hline \multirow{2}{*}{ હે } & Man & 18 & 36 \\
\hline & Woman & 32 & 64 \\
\hline \multirow{2}{*}{$\underset{\&}{\infty}$} & $\leq 20$ years old & 11 & 22 \\
\hline & $>20$ years old & 39 & 78 \\
\hline
\end{tabular}

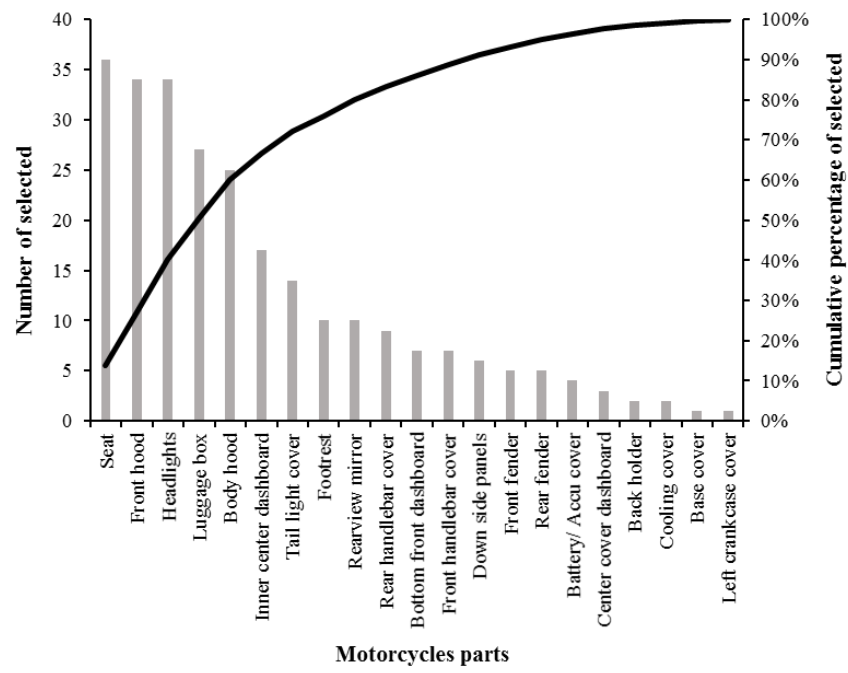

Fig. 4. Important parts of motorcycles (preliminary study result)

\subsection{Kansei words list}

By adopting the kansei words from previous researchers in designing electric vehicles [7], [10]-[12], in this research about 42 pairs of kansei words were developed which were considered by researchers and experts in the design field to represent the electric motorcycle design. All pairs of kansei words can be seen clearly in Table 3 .

\subsection{Semantic differential I}

The SD I questionnaire was distributed to 212 respondents with details in Table 4 . In this stage, it found that 14 pairs of kansei words were invalid (as seen in Table 5).

Due to 14 kansei words were invalid, the pairs of kansei words became 28 pairs $(42-14=28)$. The next step was testing the reliability of the kansei word pair that has been considered valid. The test results showed that Cronbach's Alpha value for 28 kansei word pairs was 0.864 , this value was greater than rtable (0.3673). It can be concluded that 28 pairs of kansei words were considered reliable with so high category [13].

\subsection{Factor analysis}

The results of testing KMO and Bartlett Test obtained KMO value of 0.784 with a significance of 0.000 . This indicated that the variables and existing samples can be processed using factor analysis. The factor process was done by utilizing software $\mathrm{R}$ where eigenvalue $>1$, and then 16 factors were formed from 28 pairs of kansei words. 
Table 3. Pairs of kansei word

\begin{tabular}{|c|c|c|c|}
\hline No & Kansei Word & No & Kansei Word \\
\hline 1 & Bright - Dark & 22 & Imitation - Original \\
\hline 2 & Spartan - Luxurious & 23 & $\begin{array}{l}\text { Old-Fashioned - } \\
\text { Futuristic }\end{array}$ \\
\hline 3 & Slim - Rocky & 24 & Indecisive - Decisive \\
\hline 4 & Traditional - Modern & 25 & Boring - Interesting \\
\hline 5 & Classic - Sporty & 26 & Child - Adult \\
\hline 6 & Ordinary - Unique & 27 & Static-Dynamic \\
\hline 7 & Feminine - Masculine & 28 & Plain-Patterned \\
\hline 8 & Untidy - Tidy & 29 & Weak - Strong \\
\hline 9 & Uniform - Various & 30 & Flat -Textural \\
\hline 10 & Ugly - Artistic & 31 & Rough - Smooth \\
\hline 11 & Unpolished - Polished & 32 & $\begin{array}{l}\text { Not decorative - } \\
\text { Decorative }\end{array}$ \\
\hline 12 & Personal - Universal & 33 & Rigid-Flexible \\
\hline 13 & $\begin{array}{l}\text { Uncomfortable - } \\
\text { Comfortable }\end{array}$ & 34 & Blurred-Clear \\
\hline 14 & Irregular - Regular & 35 & Narrow - Wide \\
\hline 15 & Inferior - Superior & 36 & Thin - Thick \\
\hline 16 & Complex - Simple & 37 & $\begin{array}{l}\text { Asymmetrical - } \\
\text { Symmetrical }\end{array}$ \\
\hline 17 & $\begin{array}{l}\text { Inharmonious - } \\
\text { Harmonious }\end{array}$ & 38 & Short - Long \\
\hline 18 & Abstract - Concrete & 39 & Inelegant - Elegant \\
\hline 19 & Rational-Emotional & 40 & Fragile - Tough \\
\hline 20 & Serious - Relaxed & 41 & Blunt - Taper \\
\hline 21 & Cowardly - Brave & 42 & Round - Angled \\
\hline
\end{tabular}

Table 4. Demography of respondents (SD I)

\begin{tabular}{llll}
\hline & & People & $\%$ \\
\hline \multirow{2}{*}{$๘$} & Man & 105 & 49.5 \\
\cline { 2 - 4 } & Woman & 107 & 50.5 \\
\hline \multirow{2}{*}{$\underset{\infty}{*}$} & $\leq 20$ years old & 20 & 9.4 \\
\cline { 2 - 4 } & $>20$ years old & 195 & 92.0 \\
\hline
\end{tabular}

Table 5. Invalid kansei words

\begin{tabular}{clcc}
\hline No & \multicolumn{1}{c}{ Kansei Word } & $\mathrm{r}_{\text {calculate }}$ & $\mathrm{r}_{\text {table }}$ \\
\hline 1 & Spartan - Luxurious & 0.132 & 0.279 \\
\hline 2 & Ordinary - Unique & 0.101 & 0.279 \\
\hline 3 & Untidy - Tidy & 0.068 & 0.279 \\
\hline 4 & Uniform - Various & 0.153 & 0.279 \\
\hline 5 & Personal - Universal & 0.175 & 0.279 \\
\hline 6 & Uncomfortable - Comfortable & 0.243 & 0.279 \\
\hline 7 & Complex - Simple & 0.241 & 0.279 \\
\hline 8 & Rational - Emotional & 0.045 & 0.279 \\
\hline 9 & Serious - Relaxed & 0.238 & 0.279 \\
\hline 10 & Imitation - Original & 0.011 & 0.279 \\
\hline 11 & Rough - Smooth & 0.079 & 0.279 \\
\hline 12 & Thin - Thick & 0.270 & 0.279 \\
\hline 13 & Blunt - Taper & 0.238 & 0.279 \\
\hline 14 & Not decorative - Decorative & 0.260 & 0.279 \\
\hline
\end{tabular}

Note: $\mathrm{N}=50$
The next step was picking a pair of kansei word that can represent each factor. The choice of the kansei word pair was done with the similarity of the meaning of the kansei word pair on each factor then it selected which has the greatest weight (from 16 factors to be 14 factors). The result of factor analysis was shown in Table 6 .

Table 6. Kansei words result of factor analysis

\begin{tabular}{clc}
\hline No & \multicolumn{1}{c}{ Kansei Word } & Weight \\
\hline 1 & Irregular - Regular & 0.508 \\
\hline 2 & Old-Fashioned - Futuristic & 0.960 \\
\hline 3 & Narrow - Wide & 0.955 \\
\hline 4 & Feminine - Masculine & 0.464 \\
\hline 5 & Flat - Texture & 0.426 \\
\hline 6 & Indecisive - Decisive & 0.606 \\
\hline 7 & Childish - Adult & 0.558 \\
\hline 8 & Rigid - Flexible & 0.676 \\
\hline 9 & Not Artistic - Artistic & 0.707 \\
\hline 10 & Classic - Sporty & 0.629 \\
\hline 11 & Inferior - Superior & 0.353 \\
\hline 12 & Round - Angled & 0.845 \\
\hline 13 & Weak - Strong & 0.734 \\
\hline 14 & Abstract - Concrete & 0.953 \\
\hline
\end{tabular}

\subsection{Product samples list}

At this stage, around 11 samples of electric motorcycles have been collected to be evaluated with pairs of kansei words on the semantic differential II (SD II) questionnaire. All product samples were taken online from several manufacturers. They can be seen clearly in Table 7 .

Table 7. Product sample for SD II

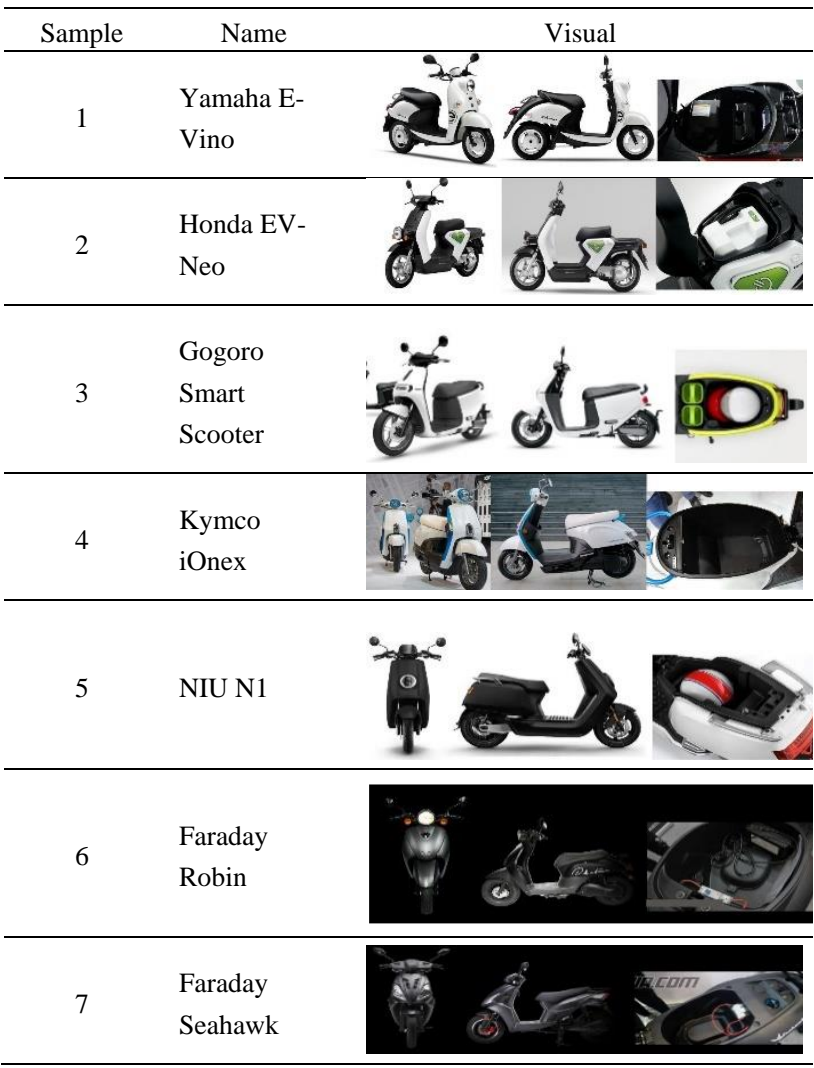




\begin{tabular}{|c|c|c|}
\hline Sample & Name & Visual \\
\hline 8 & Terra A400i & \\
\hline 9 & VIAR Q1 & \\
\hline 10 & $\begin{array}{l}\text { Luyuan } \\
\text { Scooter }\end{array}$ & \\
\hline 11 & GESITS & \\
\hline
\end{tabular}

\subsection{Item and category list}

Samples of electric motorcycles were divided into five items and 14 categories; detail of items and categories were concluded in Table 8 .

Table 8. Items and categories of electric motorcycles

\begin{tabular}{|c|c|c|c|c|}
\hline Item Name & $\begin{array}{l}\text { Item } \\
\text { Code }\end{array}$ & $\begin{array}{c}\text { Category } \\
\text { Name }\end{array}$ & Visual & $\begin{array}{l}\text { Final } \\
\text { Code }\end{array}$ \\
\hline \multirow{2}{*}{ Seat } & \multirow{2}{*}{$\mathrm{X} 1$} & 1 & & $\mathrm{X} 1.1$ \\
\hline & & 2 & & $\mathrm{X} 1.2$ \\
\hline \multirow{3}{*}{ Front Hood } & \multirow{3}{*}{$\mathrm{X} 2$} & 1 & & $\mathrm{X} 2.1$ \\
\hline & & 2 & & $\mathrm{X} 2.2$ \\
\hline & & 3 & & $\mathrm{X} 2.3$ \\
\hline \multirow{2}{*}{ Luggage Box } & \multirow{2}{*}{$\mathrm{X} 3$} & 1 & & X3.1 \\
\hline & & 2 & & X 3.2 \\
\hline \multirow{4}{*}{ Headlight } & \multirow{4}{*}{$\mathrm{X} 4$} & 1 & & $\mathrm{X} 4.1$ \\
\hline & & 2 & & X 4.2 \\
\hline & & 3 & & $\mathrm{X} 4.3$ \\
\hline & & 4 & Other & $\mathrm{X} 4.4$ \\
\hline \multirow{3}{*}{ Body Hood } & \multirow{3}{*}{$\mathrm{X} 5$} & 1 & & X5.1 \\
\hline & & 2 & & $\mathrm{X} 5.2$ \\
\hline & & 3 & Other & $\mathrm{X} 5.3$ \\
\hline
\end{tabular}

\subsection{Semantic differential II}

Semantic Differential II questionnaire was created and then it was completed by 204 respondents (detail as shown in Table 9), while the average value of the design sample can be seen in Table 10.

Table 9. Demography of respondents (SD I)

\begin{tabular}{clcc}
\hline & & People & $\%$ \\
\hline \multirow{2}{*}{} & Man & 87 & 42.6 \\
\cline { 2 - 4 } & Woman & 117 & 57.4 \\
\hline \multirow{2}{*}{$\ll$} & $\leq 20$ years old & 21 & 10.3 \\
\cline { 2 - 4 } & $>20$ years old & 183 & 89.7
\end{tabular}

Table 10. Average value of design samples

\begin{tabular}{|c|c|c|c|c|c|c|c|}
\hline & & \multicolumn{5}{|c|}{ Item Code } & \multirow{2}{*}{$\begin{array}{c}\text { Average Pairs of } \\
\text { Kansei Word }\end{array}$} \\
\hline & & $\mathrm{X} 1$ & $\mathrm{X} 2$ & $\mathrm{X} 3$ & $\mathrm{X} 4$ & X5 & \\
\hline \multirow{4}{*}{$S$} & 1 & 2 & 2 & 1 & 1 & 1 & 4.08 \\
\hline & 2 & 1 & 3 & 1 & 1 & 3 & 3.44 \\
\hline & 3 & 2 & 2 & 2 & 2 & 1 & 4.53 \\
\hline & 4 & 2 & 3 & 1 & 1 & 1 & 4.46 \\
\hline $\mathrm{a}$ & 5 & 1 & 3 & 1 & 1 & 2 & 4.88 \\
\hline \multirow{3}{*}{$\begin{array}{l}\mathrm{p} \\
1\end{array}$} & 6 & 2 & 2 & 1 & 1 & 1 & 4.55 \\
\hline & 7 & 1 & 1 & 1 & 3 & 2 & 5.36 \\
\hline & 8 & 2 & 1 & 2 & 4 & 3 & 4.09 \\
\hline \multirow{3}{*}{$\mathrm{e}$} & 9 & 2 & 2 & 1 & 2 & 1 & 3.64 \\
\hline & 10 & 2 & 2 & 1 & 4 & 1 & 3.77 \\
\hline & 11 & 2 & 1 & 1 & 3 & 2 & 5.27 \\
\hline
\end{tabular}

\subsection{Quantification theory type I}

All data in Table 10 then were used as input to the $\mathrm{R}$ program. Result of that program was coefficients of each category. By analyzing the coefficient of each category, the significant factors can be predicted.

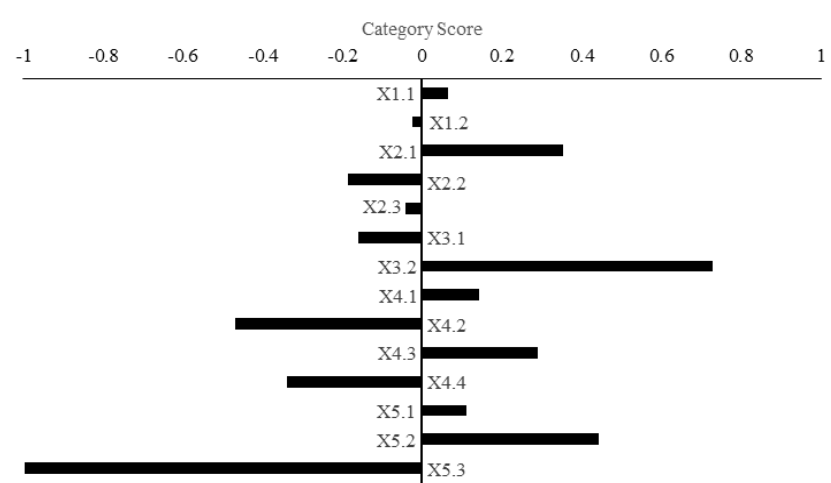

Fig. 5. Plot diagram of QT I results

Plot diagram for the results of QT I was shown in Fig. 5. From that figure, the greater the positive score in the category, the stronger the relationship with the kansei word which is on the right side or positive word. Vice versa, the greater the 
negative score in the category, the stronger the relationship with the kansei word which is on the left side or negative word. The category with the highest positive value on each item is the selected category that will be used as a combination of the final design elements [14]. In addition, the category closely related to the respondent's kansei for electric motorcycle body design namely seat shape (angled/ X1.1), front hood shape (type 1/ $\mathrm{X} 2.1$ ), number of luggage slot (2 slots/ X3.2), shape of headlight (type 3/ X4.3), and body hood (type 2/ X5.2).

The front hood, the number of luggage slot, the headlight shape, and the body hood shape have p-value below 0.05 which were considered as significant factor in predicting the variable Y (kansei word). On the other hand, seat item has p-value above 0.05 . Therefore, it was deemed as insignificant for predicting variable Y. Although it was considered insignificant statistically, in this study, it was still applied because the item has the greatest mode value on the results of the preliminary study. Therefore, it was crucial thing as consideration of respondents in choosing electric motorcycle.

\subsection{Final design}

Based on the QT I process, the design elements of the dominant electric motorcycle were combined by X1.1, X2.1, X3.2, X4.3, and X5.2. The combination can be seen in Table 11. The final design of an electric motorcycle was a combination of dominant categories and presented in Fig. 6.

Table 11. Dominant Categories of Process Results QT I

\begin{tabular}{lccc}
\hline Item Name & Final Code & Visual & Score \\
\hline Seat & $\mathrm{X} 1.1$ & 0.065 \\
\hline Front Hood & $\mathrm{X} 2.1$ & 0.353 \\
\hline Luggage Box & $\mathrm{X} 3.2$ & $\mathrm{X} 4.3$ & 0.728 \\
\hline Headlight & $\mathrm{X} 5.2$ & 0.291 \\
\hline Body Hood & & & 0.441 \\
\hline
\end{tabular}

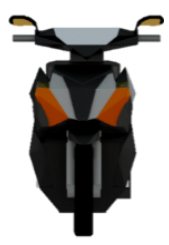

(a)

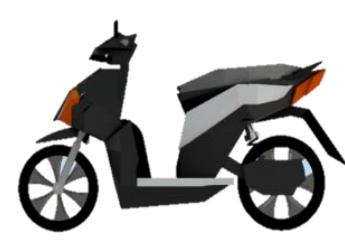

(b)

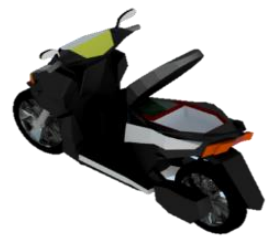

(c)

Figure 6. Final design: (a) front view; (b) side view; and (c) loop up view (open seat)

Motorcycle parts that were not included in the research design element would use the existing standards (especially for dimensions relating to human anthropometry is based on the previous study which as shown in Table 1. Final design provided the dimension for luggage box which consisted of part I $(44 \mathrm{~cm} \times 33 \mathrm{~cm} \times 14 \mathrm{~cm})$ and part II $(24 \mathrm{~cm} \times 22.5 \mathrm{~cm} \times 35$ $\mathrm{cm})$.

\section{Conclusion}

This research resulted in 14 pairs of Kansei words which were appropriate as an impression or image of electric motorcycle. The pairs of Kansei words consisted of IrregularRegular, Old-Fashioned-Futuristic, Narrow-Wide, FeminineMasculine, Flat-Texture, Indecisive-Decisive, Childish-Adult, Rigid-Flexible, Not Artistic-Artistic, Classic-Sporty, Inferior-Superior, Round-Angled, Weak-Strong, and Abstract-Concrete. These Kansei word pairs were used to evaluate 11 samples of electric motorcycle designs with 5 items and 14 categories. Design elements were chosen based on the Kansei engineering approach were angled seat (X1.1), type 1 of front hood (X2.1), 2 slots for luggage box (X3.2), type 3 of headlight (X4.3), and type 2 of body hood (X5.2). The final design of an appropriate electric motorcycle using Kansei engineering approach has been built in form of $2 \mathrm{D} / 3 \mathrm{D}$, but this design should be evaluated to confirm the benefit.

\section{References}

1. Indonesian Ministry of Energy and Mineral Resources; Media Center News Archives - Know the Types and Levels of Emission of Electric Cars (in $\quad 2017 . \quad$ Bahasa), Anline]. Available: https://www.esdm.go.id/en/media-center/news-archives/mengenal-jenisdan-tingkat-emisi-mobil-listrik. [Accessed: 11-Mar-2018].

2. Statistics Indonesia, Development of Number of Motor Vehicles by Type from 1949 to $2017,2018$.

3. M. S. H. Kamalan, Air Quality Deterioration in Tehran due to Motorcycles, J. Environ. Heal. Sci. Eng.. 2 (2005) 145-152.

4. J. Blijlevens, M. E. H. Creusen, and J. P. L. Schoormans, How consumers perceive product appearance: The identification of three product appearance attributes, Int. J. Des. 3 (2009) 27-35.

5. K. T. Ulrich and S. D. Eppinger, Product Design and Development, 384 (2012) 355-367.

6. M. Nagamachi and A. Lokman, Innovations of Kansei engineering, Boca Raton, CRC Press, 2011 pp. 1-152.

7. M. Nagamachi, Kansei Engineering and its Applications in Automotive Design, SAE Transactions 108 (2010) 2275-2282.

8. S. Schütte, Engineering Emotional Values in Product Design -Kansei Engineering in Development. Ph.D. Thesis, Linköpings University, Sweden, 2005.

9. N. H. P. R. Lestari, Design Analysis of Electric Motorcycle Size for Students with Anthropometric Approach (in Bahasa), Thesis, Gadjah Mada University, Indonesia, 2017.

10. C.-C. Liang, W.-P. Pu, H.-Y. Chang, and K.-H. Chen, Analyzing automotive interior images and their perceived-value with Kansei Engineering, Int. Conf. Kansei Eng. Emot. Res. Emot. Res., 2014.

11. M. Syed Mohamed and S. Mustafa, Kansei Engineering Implementation on Car Center Stack Designs, Int. J. Educ. Res. 2 (2014) 355-366.

12. F. Zhang and J. Wang, Application of Kansei Engineering in Electric Car Design, Appl. Mech. Mater 437 (2013) 985-989. 
13. R. Heale and A. Twycross, Validity and reliability in quantitative studies, Evid. Based Nurs, BMJ 18 (2015) 66-67.
14. M. Nagamachi, Kansei/Affective Engineering, Boca Raton, CRC Press, 2010 pp. $1-334$. 